\title{
REGULATION OF LEGAL LABOUR MIGRATION FROM THIRD COUNTRIES UNDER EU LAW
}

Diana G. Martirosyan ${ }^{1}$

\begin{abstract}
The article considers the EU legislation regulating legal labour migration from third countries, which

countries, which could be similar, for example, to the existing European job mobility portal EURES.
\end{abstract} has lately become one of the most pressing issues in the European Union. In particular, the authors consider provisions of the EU/EC Directives and cases of the Court of Justice of the European Union. They come to the conclusion that the EU institutions and bodies should take more careful approach to labour market needs, taking into account the necessary qualifications of workers. Under the current conditions of the European migrant crisis, the EU should further develop legal regulation of the general migration policy, with a particular attention to labour migration. It is necessary to establish and improve the incentives for migrants to study European languages, contributing to their integration in the EU member states. There is also a demand for the development of interactive tools helping potential migrant workers from third
Keywords: migrant, labour migration, law, directive, crisis, borders, society, member states, legal migration.

\section{Introduction}

The legal regulation of migration has long been a traditional issue of concern for such powerful international organizations as the United Nations, European Union and the Organization for Security and Co-operation in Europe.

The migration problem became especially relevant for the European Union some years ago, when some EU member states had to temporarily close their national borders within the EU due to the influx of immigrants. During that difficult period, the EU itself was on the verge of a split due to the migrant crisis, which resulted from the disagreement

\footnotetext{
${ }^{1}$ Moscow State Institute of International Relations (MGIMO University) Ministry of Foreign Affairs of the Russian Federation
} 
between the member states on the migration policy.

The issues of the control over migration processes and regulation of the influx of migrants from third countries, explored in this article, are still relevant today, because they constitute a challenge to which the EU must respond deliberately, comprehensively and efficiently.

At the same time, the EU today shows a clear economic and political interest in legal labour migration. This can be observed in the speeches of EU officials and the reports of the European Commission, which acts as one of the main initiators of projects aimed to resolve problems related to migration flows in the EU.

The relevance and urgency of the need to regulate legal labour migration is determined by several factors that are common to all EU countries, including, in particular, the following:

- population decline combined with population ageing;

- inability to ensure sustainable economic growth independently due to a lack of manpower;

- growing pressure on the social security system of the EU member states;
- labour shortage. which has already manifested itself in certain sectors of the EU internal market.

At the same time, judging from the EU reaction to the massive influx of migrants from third countries (North Africa, Middle East), the undoubted interest of the EU member states in labour resources does not mean that they are absolutely open and want to accept all aspiring immigrants.

In other words, the number of people wishing to move to the $\mathrm{EU}$ is much higher than the number that the Union is ready and willing to accept. Naturally, this implies a need for strict control over migration flows from third countries and for improvement of the legal regulation in this sphere at the level of both individual member states and the entire EU.

\section{Materials and Methods}

The main sources of legal regulation of the freedom of movement for nationals of third countries are the Treaty on the Functioning of the European Union (TFEU) and theTreaty 
on European Union (TEU) of 2007.². The Treaty on European Union, in particular, confirms the importance of establishing "an area of freedom, security and justice", which is stated as the Union's aim (Article 3 par. 2 TEU) ${ }^{3}$.

The TFEU establishes significant changes in the legal status of the nationals of third countries on the EU territory. Thus, for example, the powers of the EU institutions and bodies and of the EU member states in this sphere are specified. In accordance with Article 4 par. 2 TFEU, the shared competence between the Union and the member states applies to the area of freedom, security and justice.

Article 67 of TFEU Title V "Area of Freedom, Security and Justice" stipulates that third-country nationals are persons without EU citizenship; stateless persons are also treated as third-country nationals.

The complex of basic powers of the EU institutions in relation to third-

2 Kashkin S.Yu. (Ed.) Evropejskij sojuz: Osnovopolagajushhie akty v redakcii Lissabonskogo dogovora s kommentarijami (European Union: Establishing acts as amended by the Lisbon Treaty with commentary). Moscow: Infra-M, 2010, pp. 241-245.

${ }^{3}$ Biryukov M.M. Evropejskoe pravo: do i posle Lissabonskogo dogovora (European law: Before and after the Lisbon country nationals is described in Part 3 of the considered TFEU Title. In particular, this part of the document stipulates specific objectives for regulating and developing the following policies:

- a common policy on visas and procedures for crossing borders (both internal and external) of the EU member states (Article 77);

- a common policy on asylum (Article 78);

- a common immigration policy (Article 79).

For the purposes of our study, it is also important to consider the following key documents of secondary legislation:

- Council Directive No. 2003/109/EC of 25 November 2003 concerning the status of third-country nationals who are long-term residents. ${ }^{4}$

- Council Directive No. 2003/86/EC of 22 September 2003 on the right to family reunification. ${ }^{5}$

Treaty). Textbook. Moscow: Statut, 2013, pp. 122-123.

${ }^{4}$ Council Directive 2003/109/EC of 25 November 2003 concerning the status of third-country nationals who are long-term residents.OJ L 16, 23.01.2004.

${ }^{5}$ Council Directive 2003/86/EC of 22 September 2003 on the right to family reunification.OJ L 251, 03.10.2003. 


\section{Results}

The provisions of the abovementioned Directives introduced considerable changes to the legal status of third-country nationals, namely it has become very close to the status of EU citizens. Such status is provided only to the persons of impeccable reputation who legally reside in the EU territory and comply with all necessary formalities in their proper behaviour. In other words, residence of third-country nationals in the EU should not constitute a threat to public security of the EU member states.

Third-country nationals who apply for permanent residence must confirm legality of their prior stay in the territory of the member state for at least five years. Moreover, they must have sufficient financial means and sickness insurance,

The following persons cannot be granted permanent residence:

- students from third countries;

- seasonal workers;

- diplomats and consular officers.

Long-term residents in the European Union have the same labour rights as EU nationals, including, in particular:

- the right to entrepreneurial activity;
- access to education and

vocational training;

- recognition of professional diplomas and other qualifications;

- social security and tax benefits; etc.

Directive No. 2003/86/EC on the right to family reunification regulates the status of a special category of persons members of the family of a third-country national. According to the Directive provisions, family reunification in the territory of a EU member state is possible if the applying third-country national has been holding a legal residence permit in the EU member state for a period of one year and has reasonable prospects of obtaining the right of permanent residence.

\section{Discussion}

At first glance, the provisions of the above-mentioned directives seem beneficial to migrant workers and their family members from third countries; however, in practice it is not so easy to fully enjoy those rights. The fact is that these directives contain provisions granting authorities of the member states the right to introduce additional internal regulations that require fulfilment of certain formalities for a legal residence 
of third-country nationals in their territories. Non-compliance with such regulations can prevent third-country nationals from enjoying the rights guaranteed by the directives.

At the same time, the importance of the principle of equal treatment when dealing with third-country nationals have been repeatedly confirmed in the decisions of the Court of Justice of the European Union.

For example, in the case of Kamberaj, ${ }^{6}$ the Court of Justice considered the rejection by Social Housing Institute of the Autonomous Province of Bolzano of the application for a social benefit made by Albanian citizen Servet Kamberaj. The rejection ground was the lack of money for such benefit in the local budget. The Court decision states that the third-country nationals who are long-term legal residents have the same economic needs

${ }^{6}$ Case C-571/10 Servet Kamberaj v. Istituto per l'Edilizia sociale della Provincia autonoma di Bolzano and others [2012]. ECLI:EU:C:2012:233.

${ }^{7}$ According to Article 45 of the TFEU, the freedom of movement for workers who are nationals of the member states entails the right to accept offers of employment; to move freely to the territory of any EU member state for employment; to stay in the member state for the purpose of employment and to remain in its territory after employment in that state. The workers from as the EU citizens and should enjoy equal treatment with EU citizens as regards social assistance in accordance with the Directive concerning the status of third-country nationals who are longterm residents.

As for the right to free movement of workers within the EU market guaranteed by the $\mathrm{TFEU}^{7}$, it does not apply to third-country nationals, but has a considerable effect on them.

At the same time, Directive No. $2004 / 38$ on the right of citizens of the Union and their family members to move and reside freely within the territory of the Member States ${ }^{8}$ stipulates the right of the EU citizen's family members who are third-country nationals to employment within the EU territory. Moreover, they have the right to social assistance and benefits. The Directive is also applicable to the third-country nationals who are family members of

third countries can be guaranteed employment only within the territory a certain EU member state.

8 Directive No. 2004/38 of the European Parliament and of the Council of 29 April 2004 on the right of citizens of the Union and their family members to move and reside freely within the territory of the Member States amending Regulation No. 1612/68 and repealing Directives 64/221, 68/360, 72/194, 73/148, 75/34, 75/35, 90/364/, 90/365 and 93/96. OJ L 158, 30.04.2004. 
citizens of Iceland, Liechtenstein, Norway and Switzerland.

Another important act of secondary legislation that regulates labour migration from third countries is Directive No. 2009/50/EC of 25.05.2009 on the conditions of entry and residence of third-country nationals for the purposes of highly qualified employment ${ }^{9}$, which introduces a new type of EU residence permit (EU Blue Card) for third-country nationals for the period of up to 4 years.

The main criterion for obtaining the Blue Card, in accordance with Article 5 of the Directive, is a binding job offer for employment with the salary that shall not be inferior to the established salary threshold. ${ }^{10}$

As noted by Yu.S. Kashkin, the Blue Card was the core of the European Parliament resolution of 26.09.2007 on the Policy Plan on Legal Migration, which was later realised in the Directive. ${ }^{11}$

The Blue Card can be issued to the third-country nationals with higher

${ }^{9}$ Council Directive 2009/50/EC of 25 May 2009 on the conditions of entry and residence of third-country nationals for the purposes of highly qualified employment.OJ L 155, 18.06.2009.

${ }^{10}$ The regulations established by the Directive are not applicable in the United professional qualifications that are confirmed by a higher education qualification (on condition that the studies needed to acquire it lasted at least three years) or by at least five years of professional experience in a job requiring higher education qualifications.

After two years of legal employment, an EU Blue Card holder who is third-country national can enjoy equal treatment with EU nationals as regards access to any highly qualified employment in the EU member state of residence.

After 18 months an EU Blue Card holder can move to another EU member state for highly qualified employment. Article 15 of the Directive provides for the right of family members of a highly qualified migrant from a third country to employment in the EU, irrespective of whether they are EU citizens or not.

In 2017 the European Commission unveiled plans to reform the Blue Card system. In particular, the

Kingdom, Ireland and Denmark (states with opt-outs).

${ }^{11}$ Kashkin Yu.S. Trudovoe pravo Evropejskogo sojuza (European Union Labour Law). Textbook. Moscow: Wolters Kluwer, 2009, p. 32. 
Commission proposed to expand the rights of migrant workers with regard to:

- free movement within the EU territory;

- limiting the powers of the national authorities to regulate the residence regime for third-country nationals and family reunification procedures;

- introduction of a unified standard for all member states for attracting highly qualified specialists.

Analysing legal regulation of the labour migration, we also have to consider another act of European legislation.

In December 2011, the European Parliament and the Council adopted Directive No. 2011/98/EU on the procedure for obtaining a single permit ${ }^{12}$, which introduced a single application procedure for granting permits for residence and work in the territory of the EU member states within a single administrative act. As a result of such simplified procedure, the employment in the EU has become easier and, at the same time, the authorities can efficiently

12 Directive 2011/98/EU of the European Parliament and of the Council of 13 December 2011 on a single application procedure for a single permit for thirdcountry nationals to reside and work in the control the legality of residence and work of labour migrants from third countries within the EU territory.

In 2014, two acts were adopted to append the above-mentioned Directive and regulate the conditions of entry and stay of third-country nationals for the purpose of employment in the EU:

- Directive 2014/36/EU of the European Parliament and of the Council of 26 February 2014 on the conditions of entry and stay of third-country nationals for the purpose of employment as seasonal workers;

- Directive 2014/66/EU of the European Parliament and of the Council of 15 May 2014 on the conditions of entry and residence of third-country nationals in the framework of an intracorporate transfer.

Another important aspect of regulating the labour migration of thirdcountry nationals is the prevention of illegal immigration of third-country nationals, which is regulated by Directive No. 2009/52/EC on minimum standards on sanctions and measures against employers of illegally staying

territory of a Member State and on a common set of rights for third-country workers legally residing in a Member State.OJ L 343, 23.12.2011. 
third-country nationals. ${ }^{13}$ The Directive forbids employment of illegal migrants, establishing a system of penalties and sanctions (in administrative or criminal proceedings) to be applied in case of infringements.

\section{Conclusion}

Our analysis leads to the following conclusions:

1. In the EU territory, the access to employment for nationals of third countries is limited. Whatever the purpose is for arrival of third-country nationals to the EU, they should in any case receive a document confirming the legality of their stay in the EU (e.g., a visa, residence permit, or a work permit). The EU/EC Directives establish different levels of access to the labour markets of the EU member states for different categories of migrant workers.

Moreover, the EU institutions enacted many pieces of secondary legislation regulating the legal status of migrants. Special legislative acts were adopted to provide for better mobility and integration in the EU of various

13 Directive 2009/52/EC of the European Parliament and of the Council of 18 June 2009 providing for minimum standards on sanctions and measures against
726

groups of third-country nationals (economic migrants, highly qualified workers and members of their families).

As for their rights, some categories of migrant workers enjoy equal treatment with EU citizens.

2. Under the current conditions of the European migrant crisis, the EU should further develop legal regulation of the general migration policy. A special attention should be paid to labour migration.

We should mention that the process of forming a common migration policy at the supranational level is slow and fragmented, which inevitably entails negative consequences both for workers from third countries and for the EU. This is especially critical in the current period when EU as a union of its member states is facing a range of significant challenges, including ageing of working population, demographic imbalance, and the need to retrain middle-aged and elderly workers.

In 2014, the European Economic and Social Committee called for strengthening the role of social partners

employers of illegally staying third-country nationals.OJ L 168, 30.06.2009. 
in the discussion of a common European labour migration policy. In particular, it was stated that the division of labour migrants into different categories (highly qualified workers, seasonal workers, scientists) makes it difficult to promote an effective migration policy.

3. The EU institutions and bodies should take more careful approach to labour market needs, taking into account the necessary qualifications of workers. It is necessary to establish and improve the incentives for migrants to study European languages, contributing to their integration in the EU member states.

A very important factor is establishing personal contacts (e.g., between an employee and an employer), which so far have been underestimated in recruitment.

4. There is also a demand for the development of interactive tools helping potential migrant workers from third countries, which could be similar, for example, to the existing European job mobility portal EURES. ${ }^{14}$

5. In EU law, the migration issues and migration policy in general are regulated mainly by directives.

${ }^{14}$ EURES is a European cooperation network of employment services - a
However, although the directives are used as the tools for harmonizing the national legislations of the member states, the alignment of the legal systems of the EU member states cannot be fully achieved precisely because the directives can only set goals and minimum standards of legal regulation.

At the same time, they offer greater flexibility in the choice of regulation in accordance with national circumstances. Thus, the member states may choose the most suitable options for regulating labour migration in compliance with the provisions of these secondary legislation acts.

As a result, in law enforcement practice of the EU member states, we can often observe that different jurisdictions enact fundamentally different regulations; whilede jure they serve the purpose of harmonizing the national legislations of the EU member states, as defined in the directives, de factothey do not promote harmonization at all.

\section{References}

Davletgildeev R.Sh Mezhdunarodnopravovoe regulirovanie trudovoj migracii i akademicheskoj mobil'nosti v can find jobs or job seekers. 
Evropejskom sojuze i Evrazijskom jekonomicheskom sojuze: vozmozhnost' peredachi opyta (International legal regulation of labour migration and academic mobility in the European Union and the Eurasian Economic Union: Opportunity to exchange experiences). In Davletgildeev R.Sh (Ed.) Regional'nye aspekty integracii: Evropejskij sojuz $i$ Evrazijskoe prostranstvo (Regional aspects of integration: European Union and Eurasian space). Moscow, 2019, pp. 173-196.

Zhulikova O.V., Chayka A.M. Sovremennye tendencii trudovoj immigracii $\mathrm{V}$ Evropejskom sojuze (Current trends in labour migration in the European Union). Social'nojekonomicheskie javlenija $i$ processy, 2020, vol. 15, no. 1(108). pp. 105-116.

Melkonyan V.A. Masshtaby trudovoj migracii v strany ES (The scale of labour migration to the EU member states). Modern Science. 2019, no. 3, pp. 147151.

Clemens M., Dempster H., \& Gough K. Maximizing the shared benefits of legal migration pathways: Lessons from Germany's skills partnerships. Center for Global Development Policy Paper 150, July 2019. Available at www.cgdev.org/publication/maximizing -shared-benefits-legal-migrationpathways Accessed on: 22.05.2020. Council Directive 2009/50/EC of 25 May 2009 on the conditions of entry and residence of third-country nationals for the purposes of highly qualified employment. Available at http://data.europa.eu/eli/dir/2009/50/oj Accessed on: 22.05.2020. Consolidated text: Regulation (EC) No 883/2004 of the European Parliament and of the Council of 29 April 2004 on the coordination of social security systems. Available at http://data.europa.eu/eli/reg/2004/883/2 014-01-01 Accessed on: 22.05.2020.

Charter of Fundamental Rights of the European Union. Available at http://data.europa.eu/eli/treaty/char_201 2/oj Accessed on: 22.05.2020.

Directive 2014/36/EU of the European Parliament and of the Council of 26 February 2014 on the conditions of entry and stay of third-country nationals for the purpose of employment as seasonal workers. Available at http://data.europa.eu/eli/dir/2014/36/oj Accessed on: 22.05.2020.

Directive 2014/66/EU of the European Parliament and of the Council of 15 May 2014 on the conditions of entry and 
residence of third-country nationals in the framework of an intra-corporate transfer.

Available at http://data.europa.eu/eli/dir/2014/66/oj Accessed on: 22.05.2020.

Directive 2011/98/EU of the European Parliament and of the Council of 13 December 2011 on a single application procedure for a single permit for thirdcountry nationals to reside and work in the territory of a Member State and on a common set of rights for third-country workers legally residing in a Member State. OJ L 343, 23.12.2011.

Eurostat. Statistics Explained. Available at https://ec.europa.eu/eurostat/statisticsexplained/index.php/Main_Page

Accessed on 18.05.2020.

European Commission. Communication from the Commission to the European Parliament, the European Council and the Council: Managing migration in all its aspects: Progress under the European Agenda on Migration (COM(2018) 798). Available at https://ec.europa.eu/homeaffairs/sites/homeaffairs/files/what-wedo/policies/european-agendamigration/20181204_com-2018-798communication_en.pdf Accessed on: 22.05.2020.

European Commission. Communication from the Commission to the European
Parliament, the European Council and the Council: Progress report on the implementation of the European Agenda on Migration (COM(2019) 126). Available at https://ec.europa.eu/homeaffairs/sites/homeaffairs/files/what-wedo/policies/european-agendamigration/20190306_com-2019-126report_en.pdfAccessed on: 22.05.2020. European Commission. Commission Staff working document: Executive summary of the Fitness Check on the EU Legislation on Legal Migration (SWD(2019) 1055). Available at https://ec.europa.eu/home-affairs/whatwe-do/policies/legal-migration/fitnesscheck_en Accessed on: 22.05.2020. International Center for Migration Policy Development. Concept Note: Pilot Projects Legal Migration (2018). Available at www.icmpd.org/fileadmin/user_upload/ DOC6_Concept_Note.pdf Accessed on: 22.05.2020.

Regulation (EU) No 604/2013 of the European Parliament and of the Council of 26 June 2013 establishing the criteria and mechanisms for determining the Member State responsible for examining an application for international protection lodged in one of the Member States by a third-country national or a 
stateless person. Available at http://data.europa.eu/eli/reg/2013/604/oj Accessed on: 22.05.2020.

Regulation (EC) No 987/2009 of the European Parliament and of the Council of 16 September 2009 laying down the procedure for implementing Regulation (EC) No 883/2004 on the coordination of social security systems. Available at http://data.europa.eu/eli/reg/2009/987/oj Accessed on: 22.05.2020.

Treaty of Lisbon amending the Treaty on European Union and the Treaty establishing the European Community, signed at Lisbon, 13 December 2007. Available at http://data.europa.eu/eli/treaty/lis/sign Accessed on: 25.05.2020.

Treaty on the Functioning of the European Union (TFEU). Available at http://data.europa.eu/eli/treaty/tfeu_201

2/oj Accessed on: 22.05.2020.

UNICEF. Under-five mortality.

UNICEF Data: Monitoring the situation of children and women, September 2019. Available at https://data.unicef.org/topic/childsurvival/under-five-mortality Accessed on: 22.05 .2020 